\title{
Systematic review of the prevalence of current smoking among hospitalized COVID-19 patients in China: could nicotine be a therapeutic option?
}

\author{
Hisato Takagi ${ }^{1}$ (D) \\ Received: 6 July 2020 / Accepted: 6 August 2020 / Published online: 16 August 2020 \\ (c) Società Italiana di Medicina Interna (SIMI) 2020
}

\section{Dear Editor,}

We read with great interest the article by Farsalinos et al. [1] recently published in Internal and Emergency Medicine. The review [1] of 13 studies enrolling a total of 5960 hospitalized coronavirus disease 2019 (COVID-19) patients in China revealed unusually lower (approximately one-fourth) smoking prevalence in COVID-19 cases than that in the general population. Recent meta-analyses [2, 3], however, demonstrated that smoking was associated with worse prognosis and mortality in patients with COVID-19. To determine whether COVID-19 prevalence is modulated by smoking prevalence, meta-regression of Japanese prefectural data was herein conducted.

In each Japanese prefecture, the following was extracted: (1) number of confirmed COVID-19 cases on 15 June 2020 from the "Ministry of Health, Labour and Welfare" (https ://www.mhlw.go.jp/content/10906000/000640393.pdf); (2) smoking prevalence (\%) in 2016 (latest survey) from the "National Cancer Center Japan" (https://ganjoho.jp/reg_stat/ statistics/dl/index.html\#smoking); and (3-1) population per $1-\mathrm{km}^{2}$ inhabitable area (in 2018), (3-2) proportion (\%) of males and $<15$-year $/ \geq 65$-year subjects (in 2018), (3-3) prevalence (/100 thousands) of neoplasm, type 2 diabetes mellitus, and essential hypertension (in 2017), (3-4) yearly average air temperature $\left({ }^{\circ} \mathrm{C}\right)$, total sunshine hours (h), total precipitation ( $\mathrm{mm}$ ), and average relative humidity (\%) (in 2018), (3-5) healthy life expectancy (years) (in 2016) and

Electronic supplementary material The online version of this article (https://doi.org/10.1007/s11739-020-02473-2) contains supplementary material, which is available to authorized users.

Hisato Takagi

kfgth973@ybb.ne.jp

1 Shizuoka Medical Center, 762-1 Nagasawa, Shimizu-cho, Sunto-gun, Shizuoka 411-8611, Japan life expectancy at birth (years) (in 2015), (3-6) number (/100 thousands) of hospital beds (in 2017), doctors (in 2017), and nurses (in 2018), (3-7) monthly average households and persons assisted by livelihood protection (/1000 persons) (in 2017), and (3-8) monthly current income per household and living expenditure ( $\geq 2$-person households-workers' households) (yen) (in 2018) from the "e-Stat, Statistics of Japan" (https://www.e-stat.go.jp) (Supplementary Table S1). To adjust for prefectural population density, COVID-19 prevalence was defined as the number of COVID-19 cases divided by the population per $100-\mathrm{km}^{2}$ inhabitable area. Univariable (including smoking prevalence as only a covariate) and multivariable (including all the above-mentioned parameters as covariates) random-effects meta-regression was performed using OpenMetaAnalyst (https://www.cebm.brown.edu/ openmeta/index.html). A meta-regression graph depicted COVID-19 prevalence (plotted as logarithm-transformed prevalence on the $\mathrm{Y}$-axis) as a function of smoking prevalence (plotted on the $\mathrm{X}$-axis).

A slope of the univariable meta-regression line was significantly positive (coefficient, $0.319 ; 95 \%$ confidence interval [CI] 0.148-0.490; $p<0.001$; Fig. 1), which indicated that COVID-19 prevalence increased significantly as smoking prevalence increased. The slope was also significantly positive (coefficient, $0.321 ; 95 \%$ CI $0.093-0.549 ; p=0.006$ ) even in multivariable meta-regression including all the 22 covariates together (Table 1).

The present meta-regression suggests a positive association of smoking prevalence with COVID-19 prevalence independent of various examined covariates. Remarkably lower current-smoking prevalence in hospitalized COVID19 patients $(6.5 \%$; 95\% CI $4.9-8.2 \%)$ than that in the general population (26.6\%) in China (2018 Global Adult Tobacco Survey, https://www.who.int/docs/default-source/wpro--documents/countries/china/2018-gats-china-factsheetcn-en.pdf?sfvrsn=3f4e2da9_2) has been reported in the article by Farsalinos et al. [1], which could be explained 
Fig. 1 Meta-regression graph depicting COVID-19 prevalence (plotted as logarithmtransformed prevalence on the Y-axis) as a function of smoking prevalence (plotted on the $\mathrm{X}$-axis)

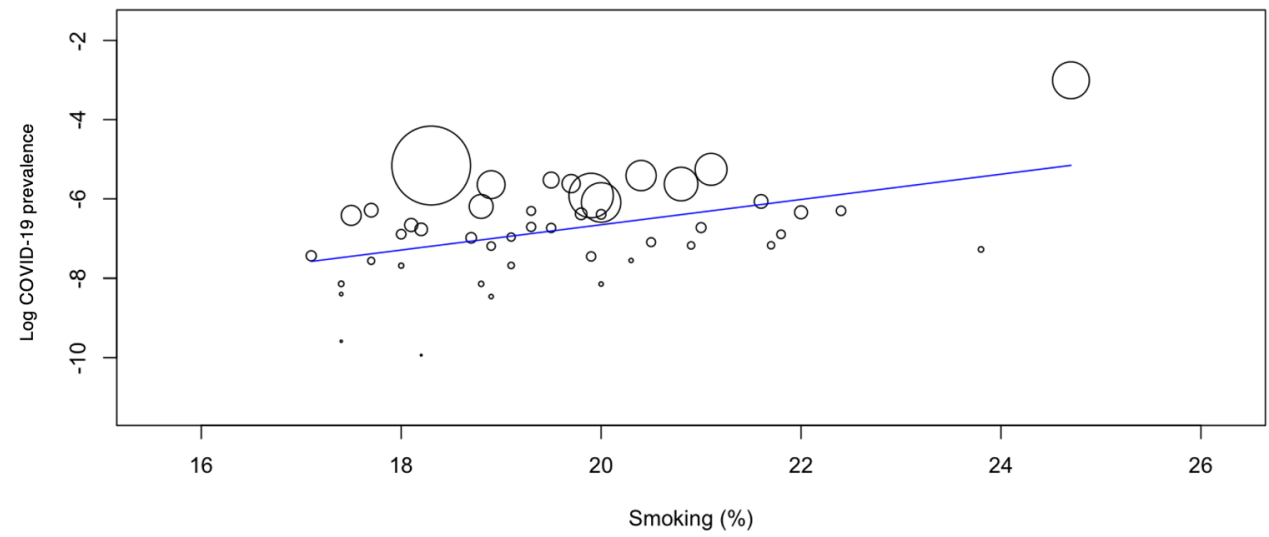

Table 1 Multivariable metaregression summary

\begin{tabular}{|c|c|c|c|c|}
\hline \multirow[t]{2}{*}{ Covariate } & \multirow[t]{2}{*}{ Coefficient } & \multicolumn{2}{|c|}{$95 \%$ confidence interval } & \multirow[t]{2}{*}{$p$ value } \\
\hline & & Lower & Upper & \\
\hline Smoking (\%) & 0.321 & 0.093 & 0.549 & 0.006 \\
\hline Male (\%) & -0.323 & -0.892 & 0.247 & 0.267 \\
\hline$<15$ years $(\%)$ & -0.452 & -1.326 & 0.423 & 0.311 \\
\hline$\geq 65$ years $(\%)$ & -0.313 & -0.659 & 0.034 & 0.077 \\
\hline Neoplasm (/100 thousands) & -0.000 & -0.000 & 0.000 & 0.577 \\
\hline Type 2 diabetes mellitus (/100 thousands) & 0.007 & -0.002 & 0.015 & 0.116 \\
\hline Essential hypertension (/100 thousands) & -0.009 & -0.021 & 0.003 & 0.136 \\
\hline Yearly average air temperature $\left({ }^{\circ} \mathrm{C}\right)$ & 0.146 & -0.166 & 0.457 & 0.359 \\
\hline Yearly total sunshine hours (h) & -0.001 & -0.003 & 0.001 & 0.178 \\
\hline Yearly total precipitation $(\mathrm{mm})$ & 0.000 & -0.001 & 0.001 & 0.905 \\
\hline Yearly average relative humidity $(\%)$ & -0.036 & -0.116 & 0.043 & 0.371 \\
\hline Healthy life expectancy, male (years) & 0.077 & -0.537 & 0.692 & 0.805 \\
\hline Healthy life expectancy, female (years) & 0.247 & -0.170 & 0.664 & 0.246 \\
\hline Life expectancy at birth, male (years) & 0.652 & -0.567 & 1.870 & 0.294 \\
\hline Life expectancy at birth, female (years) & -0.404 & -1.911 & 1.102 & 0.599 \\
\hline Hospital beds (/100 thousands) & -0.001 & -0.003 & 0.002 & 0.708 \\
\hline Doctors (/100 thousands) & -0.010 & -0.024 & 0.003 & 0.127 \\
\hline Nurses (/100 thousands) & 0.003 & -0.003 & 0.010 & 0.354 \\
\hline $\begin{array}{l}\text { Monthly average households assisted by liveli- } \\
\text { hood protection (/1000 households) }\end{array}$ & -0.206 & -0.440 & 0.028 & 0.085 \\
\hline $\begin{array}{l}\text { Monthly average persons assisted by livelihood } \\
\text { protection (/1000 persons) }\end{array}$ & 0.379 & -0.003 & 0.762 & 0.294 \\
\hline Monthly current income per household (yen) & 0.000 & -0.000 & 0.000 & 0.883 \\
\hline Monthly living expenditure (yen) & 0.000 & -0.000 & 0.000 & 0.520 \\
\hline
\end{tabular}

by nicotine-induced downregulation of the angiotensin converting enzyme 2 (ACE2) receptor [4], i.e. the receptor for severe acute respiratory syndrome coronavirus 2 causing COVID-19. This hypothesis, however, may be negated by the present findings of the positive association of smoking prevalence with COVID-19 prevalence in Japan. The interplay between smoking and COVID-19 may be exceedingly complicated and should not be oversimplified by the ACE2 hypothesis. Despite well documenting the smoking risk on health, tobacco/cigarette smoke (e.g. nicotine, carbon monoxide, and menthol) is experimentally known to positively modulate the immune system and may exert both harmful and beneficial influences [5]. The main limitations of the present analysis included relatively small number of COVID-19 cases in each prefecture and latest survey of smoking prevalence 4 years before the study period investigating COVID-19 prevalence in 2020 . It should be noted that the present results do not denote directly that smokers are at high risk for COVID-19. The present findings demonstrate simply that the COVID-19 prevalence is higher in the 
prefecture where smoking prevalence is higher. However, the present results could be strengthened and explained by the reported association of smoking with worse prognosis and mortality in COVID-19 patients [1,2].

In conclusion, smoking may be independently associated with COVID-19, which should be confirmed by further experimental, clinical and epidemiological investigations.

\section{Compliance with ethical standards}

Conflict of interest The authors declare that they have no conflict of interest.

Human and animal rights Not applicable.

Informed consent Not applicable.

\section{References}

1. Farsalinos K, Barbouni A, Niaura R (2020) Systematic review of the prevalence of current smoking among hospitalized COVID-19 patients in China: could nicotine be a therapeutic option? Intern Emerg Med. https://doi.org/10.1007/s11739-020-02355-7

2. Zheng Z, Peng F, Xu B, Zhao J, Liu H, Peng J, Li Q, Jiang C, Zhou Y, Liu S, Ye C, Zhang P, Xing Y, Guo H, Tang W (2020) Risk factors of critical \& mortal COVID-19 cases: a systematic literature review and meta-analysis. J Infect. https://doi.org/10.1016/j. jinf.2020.04.021

3. Zhao Q, Meng M, Kumar R, Wu Y, Huang J, Lian N, Deng Y, Lin S (2020) The impact of COPD and smoking history on the severity of Covid-19: a systemic review and meta-analysis. J Med Virol. https://doi.org/10.1002/jmv.25889

4. Oakes JM, Fuchs RM, Gardner JD, Lazartigues E, Yue X (2018) Nicotine and the renin-angiotensin system. Am J Physiol Regul Integr Comp Physiol 315:R895-R906

5. Polosa R, Caci G (2020) COVID-19: counter-intuitive data on smoking prevalence and therapeutic implications for nicotine. Intern Emerg Med. https://doi.org/10.1007/s11739-020-02361-9

Publisher's Note Springer Nature remains neutral with regard to jurisdictional claims in published maps and institutional affiliations. 